\title{
Hydrochemistry of Groundwater in the Aquifer AQ-2 in Pointe-Noire, South-West Congo-Brazzaville
}

\author{
${ }^{1} \mathrm{C}$. Tathy, ${ }^{2} \mathrm{~L}$. Matini, ${ }^{1} \mathrm{~B}$. Mabiala, ${ }^{3} \mathrm{~F}$. Antoine and ${ }^{1} \mathrm{G}$. Moukandi Nkaya \\ ${ }^{1}$ Equipe De Recherche En Materiaux et Ecoulements En Milieux Poreux, \\ ENSP, U.M.NG., B.P 69 Brazzaville, Congo \\ ${ }^{2}$ Laboratoire De Chimie Minerale et Appliquee, Faculte Des Sciences, \\ U.M.NG. B.P 69 Brazzaville, Congo \\ ${ }^{3}$ Groupe De Recherche En Sciences Exactes et Naturelles, GERSEN-DGRST, \\ B.P 2499 Brazzaville, Congo
}

\begin{abstract}
The hydrochemistry of groundwater from aquifer AQ-2 exploited by the National Company of Water supply (NCWD) located at Pointe-Noire, south-west of Congo-Brazzaville was evaluated for drinking water. Eleven piezometers were sampled. The physical parameters $(\mathrm{pH})$, Electric Conductivity $(\mathrm{EC})$, Total Dissolved Solids (TDS) as well as the concentrations in major ions $\mathrm{Ca}^{2+}, \mathrm{Mg}^{2+}, \mathrm{Na}^{+}, \mathrm{K}^{+}, \mathrm{Cl} ; \mathrm{SO}_{4}^{2-}, \mathrm{HCO}_{3}$ are within the WHO prescribed limits for drinking water. Two chemical facies are predominant mixed cations $\mathrm{HCO}_{3}(36.36 \%)$ and $\mathrm{Ca}-\mathrm{Mg}-\mathrm{HCO}_{3}(27.27 \%)$. Water-rock interaction characterized by the dissolution of carbonates and silicates plays a primordial role in the chemical composition of the groundwater. The $\mathrm{Na} / \mathrm{K}$ ratio makes it possible to classify the piezometers in three groups which were also revealed by hierarchical cluster analysis. The hydrochemical study of the aquifer $\mathrm{AQ}-2$ showed that the major cations and anions, the $\mathrm{pH}$, electric conductivity, the total dissolved solids, total alkalinity and the total hardness which characterize the chemical composition of the tablecloth are within the limits allowed for the drinking water according to standards WHO.
\end{abstract}

Key words: Hydrochemistry, aquifer, chemical facies, cluster analysis, $\mathrm{pH}$, tablecloth

\section{INTRODUCTION}

Water quality is of great importance in human life. The aquifers constitute groundwaters tanks of a vital need for the human. Groundwaters are the subject of several studies related to their quality (Aris et al., 2007). In Pointe-Noire, harbour city and economic capital located at the south-west of Congo, the principal source of supply water for human consumption is a tablecloth of deep sands exploited by the National Company of Water Distribution (N.C.W.D).

The demographic growth and the industrial activity make that this water resource is more and more exploited. In order to maintain a long-lasting development, the quality of the water resource must be acceptable. The geochemistry of the coastal aquiferous systems such is the case of Pointe-Noire tablecloth is an effective means which permits to control the salinisation. The objective of this study is to evaluate the hydrochimy of tablecloth AQ-2 of Pointe-Noire and to determine the hydrogeochemical process which controls its composition.

\section{MATERIALS AND METHODS}

Presentation of area study: The area of Pointe-Noire which is chosen for this study is located on the Atlantic coast of central Africa at the south-western extremity of Congo-Brazzaville and its geographical co-ordinates lie between the meridian lines $11^{\circ} 30$ and $12^{\circ}$ East and parallels $4^{\circ} 30$ and $5^{\circ}$ South (Fig. 1). Its surface which is approximately about 15.660 ha spread out within a radius of $15 \mathrm{~km}$.

Presenting a dominating geographical position to which it owes its most characteristic features, the studied area is an ideal zone of the contact ocean-continent where the effects of the marine currents and mass of Atlantic maritime air were announced. Annual precipitations are relatively moderate on average $1200 \mathrm{~mm}$ compared to the whole of the country. The average temperatures range between 22.2 and $28^{\circ} \mathrm{C}$ with weak thermal variations. Belonging to the coastal sedimentary basin of cretaceous and tertiary age, the area of Pointe-Noire is covered by formations with ages pliopleistocenes formations other than the series of circuses

Corresponding Author: C. Tathy, Equipe De Recherche En Materiaux et Ecoulements En Milieux Poreux, ENSP, U.M.NG., B.P 69 Brazzaville, Congo 


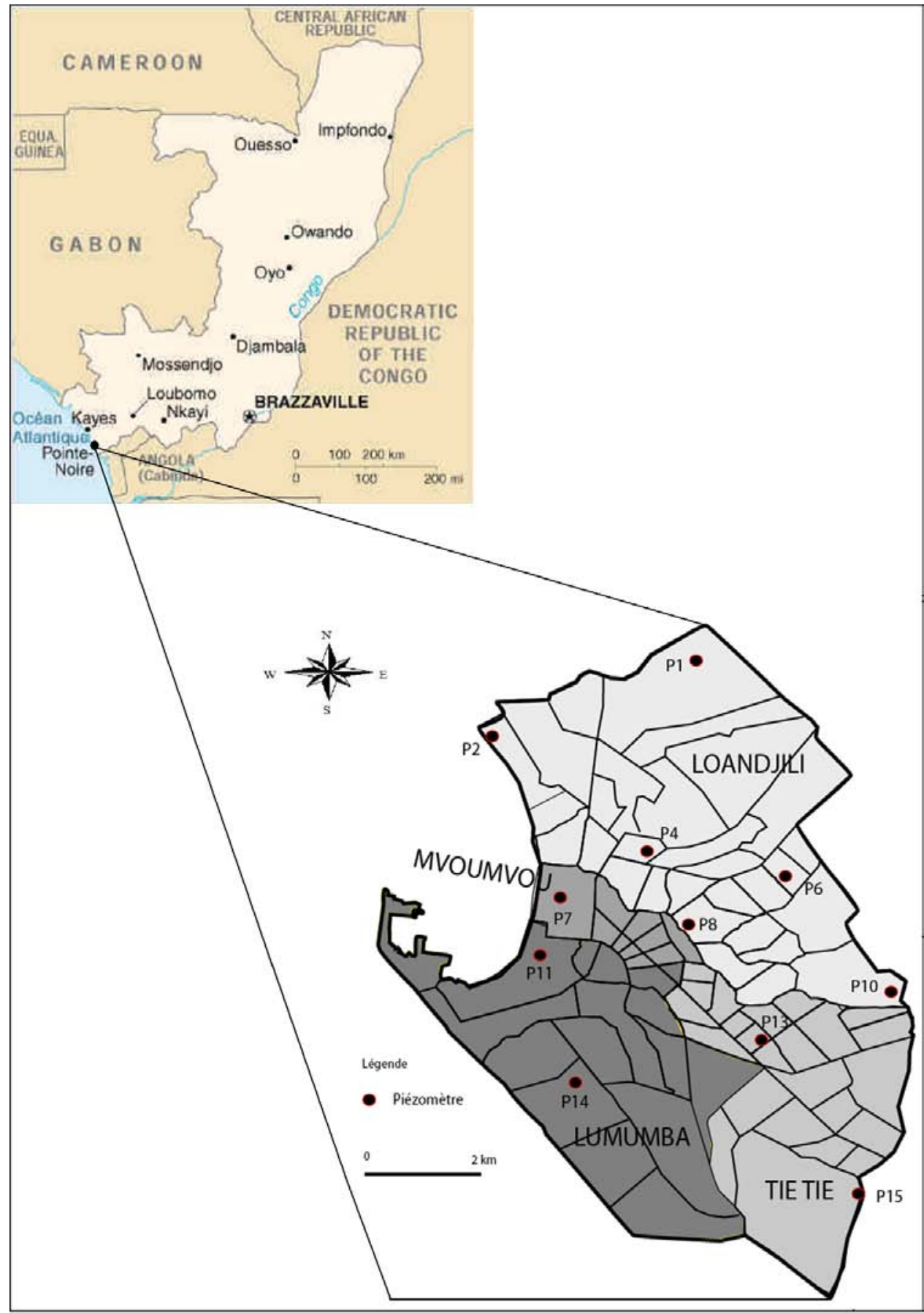

Fig. 1: Localization of the piezometers in the domain study

(Fig. 2) made of very permeable sands including multiple resistant horizons. The classification of FAO arranges the grounds of the region of Pointe-Noire in the Ferralic Arenosols group with a sandy texture (80-90\%) on $>1 \mathrm{~m}$.

The aquiferous tank of Pointe-Noire is of deep sands type belonging to the category of the permeable layers to semi permeable which endows it with the potentiality in drinking water provisioning. The present study concerns one of the two higher aquifers, aquifer AQ-2, the most exploited of the region (Fig. 3).

Experiment: To characterize the chemical composition of aquifer AQ-2, 11 piezometers of N.C.W.D whose 
Res. J. Applied Sci., 5 (5): 361-369, 2010

\begin{tabular}{|c|c|c|c|}
\hline ETAGES & FORMATIONS & LITHOLOGIE & EPAISSEUR \\
\hline PLIO-IV & Série des Cirques & & \\
\hline MIOCENE & $\begin{array}{l}\text { F. Argilo-Sableuse } \\
\text { de Pa'oukou }\end{array}$ & {$\left[\begin{array}{l}-1 \\
-1-1\end{array}\right.$} & $\sim 800 \mathrm{~m}$ \\
\hline $\begin{array}{l}\text { EOCENE } \\
\text { PALEOCENE-SENONIEN }\end{array}$ & $\begin{array}{l}\text { Marnes de Madingo } \\
\text { Silts d'Emeraude }\end{array}$ & $\begin{array}{l}-\perp \frac{1}{}+\perp \perp \\
-\perp \frac{1}{\perp} \perp\end{array}$ & $\sim 600 \mathrm{~m}$ \\
\hline TURONIEN & Dolomies de Loango & 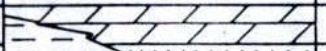 & $\sim 100 \mathrm{~m}$ \\
\hline CENOMANIEN & $\begin{array}{l}\text { Silto-agileux de Likouala } \\
\text { Grès de Tchala }\end{array}$ & & 300 à $500 \mathrm{~m}$ \\
\hline ALBIEN & $\begin{array}{l}\text { F. des Carbonates } \\
\text { de Sendji }\end{array}$ & & 100 à $1300 \mathrm{~m}$ \\
\hline APTIEN & $\begin{array}{l}\text { F. Salifère } \\
\text { de Loémé }\end{array}$ & $\begin{array}{l}L L L L L L L \\
L L L L L L \\
L L L L L L L\end{array}$ & $>1000 \mathrm{~m}$ \\
\hline---- & Sables de chéla & 4 & 15 à $60 \mathrm{~m}$ \\
\hline NEOCOMIEN & $\begin{array}{l}\text { Carbonates de Toca } \\
\text { F. Argiles de } \\
\text { Pointe-Indienne }\end{array}$ & $a^{1}$ & $>800 \mathrm{~m}$ \\
\hline - & $\begin{array}{c}\text { F. Marnes } \\
\text { de Pointe-Noire }\end{array}$ & & 300 à $700 \mathrm{~m}$ \\
\hline \multirow{3}{*}{ NEOCOMIEN } & $\begin{array}{l}\text { F. des Grès } \\
\text { de Djéno }\end{array}$ & {$[-7]$} & 300 à $000 \mathrm{~m}$ \\
\hline & $\begin{array}{l}\text { F. Marnes } \\
\text { de Sialivakou }\end{array}$ & {$\left[\begin{array}{l}\perp \perp \perp \perp \\
\perp \perp \perp \perp\end{array}\right]$} & 130 à $800 \mathrm{~m}$ \\
\hline & $\begin{array}{l}\text { F. des Grès } \\
\text { de Vandji }\end{array}$ & 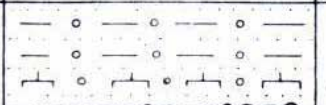 & 50 à $800 \mathrm{~m}$ \\
\hline PRECAMBRIEN & Socle & $t_{+}+t_{+}+t_{+}+$ & \\
\hline
\end{tabular}

Fig. 2: Cross section of the lithostratigraphic column of Pointe-Noire

localization is shown in Fig. 1 were sampled. Sampling was carried out during the dry season (July and August, 2009). The hydrochimy of groundwater was essentially based on the determination of the basic parameters which are $\mathrm{pH}$, temperature, Electric Conductivity (EC), Total Dissolved Solids (TDS), Calcium $\left(\mathrm{Ca}^{2+}\right)$, Magnesium $\left(\mathrm{Mg}^{2+}\right)$, Sodium
$\left(\mathrm{Na}^{+}\right)$, Potassium $\left(\mathrm{K}^{+}\right)$, Chloride $\left(\mathrm{Cl}^{-}\right)$, Sulphate $\left(\mathrm{SO}_{4}{ }^{-2}\right)$, bicarbonate $\left(\mathrm{HCO}_{3}\right)$, Total Hardness $(\mathrm{TH})$ and Total Alkalinity (TA). The water samples were taken in polyethylene bottles of one liter capacity initially washed with nitric acid $1 \mathrm{M}$ and distilled water. On the site, the bottles were washed three times with water to be analyzed 
Res. J. Applied Sci., 5 (5): 361-369, 2010
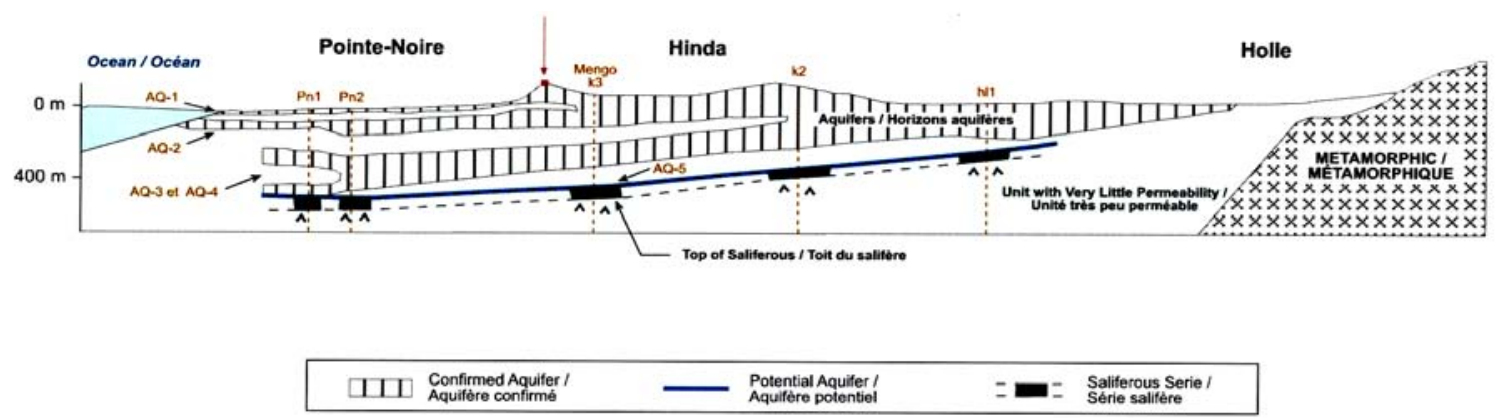

$\stackrel{0}{2}^{2} 4 \mathrm{~km}$

Fig. 3: Vertical cross section of the multi-layer aquiferous system of Pointe-Noire

then transported to the laboratory in a refrigerator at the temperature of $4^{\circ} \mathrm{C}$. The measurement of the $\mathrm{pH}$, Electric Conductivity (EC) and the Total Dissolved Solids (TDS) was made on the ground using the multi standard parameter Consort C933. The determination of the concentrations in cations and major anions was made according to the standardized methods (APHA/AWWA, 1995). The statistical data processing was made with the software Statistica 7.1. The distribution of electric conductivity was represented using the software Surfer 8.0 .

\section{RESULTS AND DISCUSSION}

The chemical composition of the water samples taken on the level of the 11 piezometers and the descriptive statistics of the studied parameters are shown, respectively in Table 1 and 2 . The $\mathrm{pH}$ of the water samples varies between 5.9 and 7.2 with an average of 6.73 . The values of $\mathrm{pH}$ of the samples collected in the piezometers P4 (LOANDJLI) and P1 5 (MPAKA) are $<6.5$ which is the WHO lower limiting value (WHO, 2004) for the drinking water. Concerning the water samples from the other piezometers, the value of the $\mathrm{pH}$ is within the acceptable limits for the drinking water (6.5-8.5). Electric conductivity varies between 27 and $685 \mu \mathrm{S} \mathrm{cm}{ }^{-2}$ with an average of $225.75 \mu \mathrm{S} \mathrm{cm}^{-2}$. The water samples of the piezometers P15 and P11, respectively have the lowest and highest electric conductivity. Figure 4 shows the distribution of electric conductivity in the zone of study. One observes an increase of the latter from the south-east to the west of the zone of study which is closer to the sea. The total dissolved solids present values varying between 41.16 and $229.1 \mathrm{mg} \mathrm{L}^{-1}$. The average value of the total dissolved solids is $104.84 \mathrm{mg} \mathrm{L}^{-1}$. The TDS values are within the acceptable limits of WHO for drinking water because they are $<500 \mathrm{mg} \mathrm{L}^{-1}$ (WHO, 2004). Low values of electric conductivity and the total dissolved solids are explained by the nature of the aquifer which is sandy.

Concentrations in major cations $\mathrm{Ca}^{2+}, \mathrm{Mg}^{2+}, \mathrm{Na}^{+}, \mathrm{K}^{+}$ vary, respectively between 4.67-49, 0.7-60.48, 0.94-135.9, $2.2-7.1 \mathrm{mg} \mathrm{L}^{-1}$. The average values in major cations are respectively $25.08,16.76,43.64$ and $4.03 \mathrm{mg} \mathrm{L}^{-1}$. As for the major anions $\left(\mathrm{Cl}^{-}, \mathrm{SO}_{4}{ }^{2-}, \mathrm{HCO}_{3}^{-}\right)$, their concentrations vary, respectively between 0.8-7.3, 2.47-18, 15.13-61 $\mathrm{mg} \mathrm{L}^{-1}$ with a respective average value of 3.2 , 14.31 and $35.64 \mathrm{mg} \mathrm{L}^{-1}$. The concentrations in major cations and anions are all within the acceptable limits for the drinking water (WHO, 2004).

The composition relating to a cation or anion was expressed as a percentage of meq $\mathrm{L}^{-1}$ of the total of the cations or the anions (Fig. 5). The order of prevalence of the cations and anions expressed as a percentage of meq $\mathrm{L}^{-1}$ based on the average calculated with the whole of the wells is respectively:

$$
\mathrm{Ca}^{2+}>\mathrm{Na}^{+}>\mathrm{Mg}^{2+}>\mathrm{K}^{+} ; \mathrm{HCO}_{3}>\mathrm{SO}_{4}{ }^{2-}>\mathrm{Cl}^{-}
$$

From Fig. 5 one notices also an excess of the cations $\mathrm{Ca}^{2+}+\mathrm{Mg}^{2+}$ compared to the cations $\mathrm{Na}^{+}+\mathrm{K}^{+}$. The Total Alkalinity (TA) due primarily to the ions bicarbonates $\left(\mathrm{HCO}_{3}\right)$ varies between 12.4 and $50 \mathrm{mg} \mathrm{L}^{-1} \mathrm{CaCO}_{3}$. As for Total Hardness (TH) due to the ions $\mathrm{Ca}^{2+}$ and $\mathrm{Mg}^{2+}$ it varies between 14.54 and $371.41 \mathrm{mg} \mathrm{L}^{-1} \mathrm{CaCO}_{3}$ with an average value of $131.64 \mathrm{mg} \mathrm{L}^{-1} \mathrm{CaCO}_{3}$. The low values of Total Hardness (TH) as those of the total dissolved solids make it possible to classify water of aquifer AQ-2 as being soft (Ravindra and Gark, 2007).

The geochemical evolution of groundwater being studied can be understood by plotting the diagram of Piper (Fig. 6). In the diagram of the cations one observes piezometers in the medium of the triangle not presenting 
Res. J. Applied Sci., 5 (5): 361-369, 2010

Table 1: Chemical composition of water samples in Pointe-Noire

\begin{tabular}{|c|c|c|c|c|c|c|c|c|c|c|c|c|c|c|}
\hline Code & Locate & $\mathrm{pH}$ & $\mathrm{CE}$ & TDS & $\mathrm{T}$ & $\mathrm{Ca}^{2+}$ & $\mathrm{Mg}^{2+}$ & $\mathrm{Na}^{+}$ & $\mathrm{K}^{+}$ & $\mathrm{Cl}^{-}$ & $\mathrm{SO}_{4}{ }^{2-}$ & $\mathrm{HCO}_{3-}$ & $\mathrm{TA}$ & $\mathrm{TH}$ \\
\hline P1 & TCHIALI & 6.8 & 69.6 & 41.16 & 26.0 & 6.00 & 3.60 & 0.94 & 2.20 & 2.5 & 8.00 & 28.06 & 23.00 & 29.81 \\
\hline P2 & CORAF & 6.7 & 68.4 & 43.12 & 26.2 & 6.20 & 3.48 & 1.45 & 2.41 & 1.9 & 8.61 & 30.02 & 24.61 & 29.81 \\
\hline P4 & LOANDJLI & 5.9 & 35.8 & 54.38 & 26.9 & 4.67 & 0.70 & 12.27 & 2.90 & 3.9 & 12.00 & 32.94 & 27.00 & 14.54 \\
\hline P6 & NKOUIKOU & 6.6 & 29.3 & 47.13 & 26.6 & 19.40 & 0.96 & 16.06 & 5.00 & 1.2 & 9.52 & 15.13 & 12.40 & 52.40 \\
\hline P7 & ORSTOM & 7.0 & 621.0 & 126.50 & 26.3 & 35.60 & 16.31 & 38.16 & 3.02 & 3.9 & 32.00 & 47.64 & 39.05 & 156.06 \\
\hline P8 & MATENDE & 6.6 & 29.7 & 53.21 & 26.0 & 11.90 & 0.96 & 2.67 & 3.60 & 1.7 & 6.87 & 28.06 & 23.00 & 33.67 \\
\hline P10 & VOUNGOU & 7.2 & 30.2 & 229.10 & 26.8 & 49.00 & 60.48 & 159.00 & 7.10 & 1.4 & 16.90 & 22.31 & 18.29 & 371.41 \\
\hline P11 & CERCLE & 7.2 & 685.0 & 140.00 & 26.8 & 38.00 & 17.00 & 35.52 & 3.70 & 4.9 & 35.00 & 61.00 & 50.00 & 164.89 \\
\hline P13 & MBOUKOU & 6.6 & 280.2 & 49.10 & 26.8 & 20.08 & 0.89 & 12.73 & 2.70 & 0.8 & 2.47 & 31.72 & 26.00 & 53.80 \\
\hline P14 & BRASCO & 7.0 & 607.0 & 140.80 & 26.8 & 43.00 & 20.00 & 65.34 & 6.10 & 7.3 & 8.00 & 46.36 & 38.00 & 189.73 \\
\hline \multirow[t]{2}{*}{ P15 } & MPAKA & 6.4 & 27.0 & 228.90 & 26.0 & 42.00 & 60.00 & 135.90 & 5.60 & 5.7 & 18.00 & 48.80 & 40.00 & 351.95 \\
\hline & $\begin{array}{l}\text { WHO guides } \\
\text { value }\end{array}$ & $6.5-8.5$ & 300.0 & 500.00 & 25.0 & 75.00 & 30.00 & 200.00 & - & 250.0 & 150.00 & 300.00 & - & 300.00 \\
\hline
\end{tabular}

Excepted pH, $\mathrm{EC}\left(\mu \mathrm{sm}^{-1}\right), \mathrm{T}\left({ }^{\circ} \mathrm{C}\right)$, $\mathrm{TA}\left(\mathrm{mg} \mathrm{L}^{-1} \mathrm{CaCO}_{3}\right)$ and $\mathrm{TH}\left(\mathrm{mg} \mathrm{L}^{-1} \mathrm{CaCO}_{3}\right)$, all other parameters are expressed in $\mathrm{mg} \mathrm{L}^{-1}$

Table 2: Descriptive statistics of the parameters

\begin{tabular}{lrrrrr}
\hline Parameters & Minimum & Maximum & Average & \multicolumn{1}{c}{ SD } & Variance \\
$\mathrm{pH}$ & 5.90 & 7.20 & 6.73 & 0.38 & 0.14 \\
$\mathrm{CE}$ & 27.00 & 685.00 & 225.75 & 274.85 & 75544.19 \\
$\mathrm{TDS}$ & 41.16 & 229.05 & 104.84 & 73.02 & 5332.09 \\
$\mathrm{~T}$ & 26.00 & 26.90 & 26.47 & 0.37 & 0.14 \\
$\mathrm{Ca}^{2+}$ & 4.67 & 49.00 & 25.08 & 16.81 & 282.52 \\
$\mathrm{Mg}^{2+}$ & 0.70 & 60.48 & 16.76 & 22.69 & 515.05 \\
$\mathrm{Na}^{+}$ & 0.94 & 159.03 & 43.64 & 55.11 & 3037.19 \\
$\mathrm{~K}^{+}$ & 2.20 & 7.10 & 4.03 & 1.66 & 2.74 \\
$\mathrm{Cl}^{-}$ & 0.80 & 7.30 & 3.20 & 2.11 & 4.44 \\
$\mathrm{SO}_{4}{ }^{2-}$ & 2.47 & 35.00 & 14.31 & 10.48 & 109.73 \\
$\mathrm{HCO}_{3}{ }^{-}$ & 15.13 & 61.00 & 35.64 & 13.57 & 184.27 \\
$\mathrm{TA}^{\mathrm{TH}}$ & 12.40 & 50.00 & 29.21 & 11.13 & 123.80 \\
& 14.54 & 371.41 & 131.64 & 129.42 & 16749.14 \\
\hline
\end{tabular}

predominance (P1, P2, P7, P10, P11, P14 and P15). On the other hand the piezometer $\mathrm{P} 4$ presents a predominance in $\mathrm{Na}^{+}$, the piezometers $\mathrm{P} 6, \mathrm{P} 8$ and $\mathrm{P} 13$ present a predominance in $\mathrm{Ca}^{2+}$. In the diagram of the anions, all the piezometers are close to the bicarbonated pole except P10 which does not present predominance. The analyzed water samples set out again in the zones of following chemical facies: mix cations $\mathrm{HCO}_{3}\left(\mathrm{Ca}-\mathrm{Na}-\mathrm{HCO}_{3}, \mathrm{Na}-\mathrm{Ca}-\right.$ $\mathrm{HCO}_{3}$, Na-Mg- $\mathrm{HCO}_{3}$ ) accounting for $36.37 \%$ of the total of the piezometers, $\mathrm{Ca}-\mathrm{HCO}_{3}(27.27 \%), \mathrm{Ca}-\mathrm{Mg}-\mathrm{HCO}_{3}$ $(18.18 \%), \mathrm{Na}-\mathrm{HCO}_{3}$ and $\mathrm{Na}-\mathrm{Mg}-\mathrm{HCO}_{3}-\mathrm{SO}_{4}$ representing each one $9.09 \%$ of the piezometers (Table 3). The meteoric influence of water $\mathrm{S}$ is clear in the studied tablecloth.

The hydrochimy of the tablecloth was also characterized by various ionic ratios (Table 3 ). The $\mathrm{Ca} / \mathrm{Mg}$ ratio is caracteristic of course of subsoil waters, variable between 0.42 and 13.54. The strongest values were observed in water of the piezometers P6, P8 and P13. This could be explained by a more significant time of residence on these piezometers.

$\mathrm{The} \mathrm{Na} / \mathrm{Ca}$ ratio varies between 0.14 and 2.82. For values $<0.80$, sodium impoverishment of groundwater being studied is very characteristic. The $\mathrm{Na} / \mathrm{K}$ ratio is about 47 for sea water and $<10$ for rainwater. This report/ratio divides water of the piezometers into three

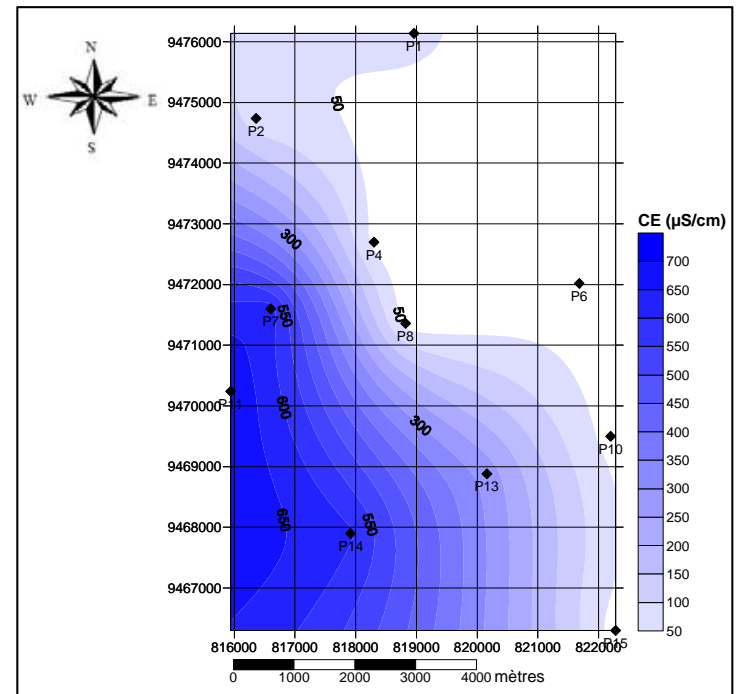

Fig. 4: Distribution of electric conductivity of water samples of the piezometers

groups: the first group is consisted of the piezometers $\mathrm{P} 1$, $\mathrm{P} 2, \mathrm{P} 4, \mathrm{P} 6, \mathrm{P} 8$ and $\mathrm{P} 13$ with a $\mathrm{Na} / \mathrm{K}$ ratio $<10$ which shows the influence of rainwater. The water samples taken in these piezometers have the low values of the Total Alkalinitry (TA) and of Total Hardness (TH); the second group is formed by the piezo meters P7, P11 and P14 whose $\mathrm{Na} / \mathrm{K}$ ratio in the water samples is slightly higher than that of rainwater.

The values of TA and $\mathrm{TH}$ are higher than those of the first group and lower than those of the third group; the third group gathers the piezometers $\mathrm{P} 10$ and $\mathrm{P} 15$ to which the $\mathrm{Na} / \mathrm{K}$ ratio is lower or close with that to sea water. The values of TA and TH are highest in the zone of study. The $\mathrm{Na} / \mathrm{Na}+\mathrm{Cl}$ ratio is $>1$ in all the analyzed water samples. The values higher than 0.5 of this ratio represent the process of ionic exchange between $\mathrm{Ca}^{2+}$ and $\mathrm{Na}^{+}$on 


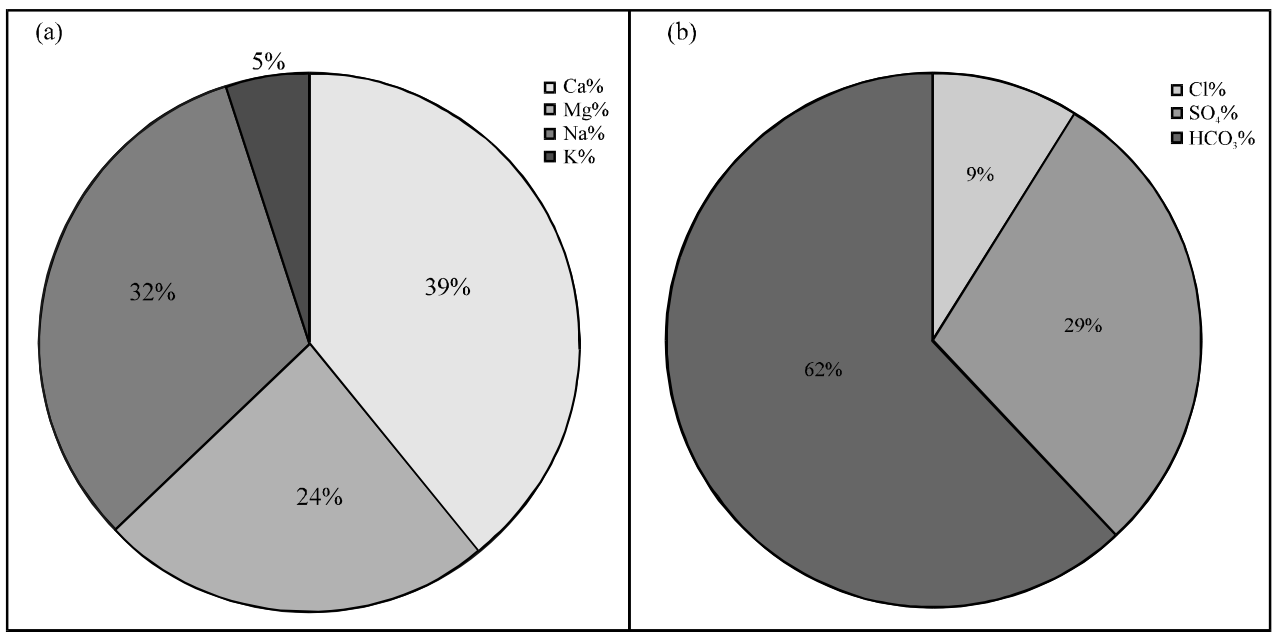

Fig. 5: Average composition in $\%$ meq $\mathrm{L}^{-1}$ of the major cations (a) and major anions (b) of water in zone of study

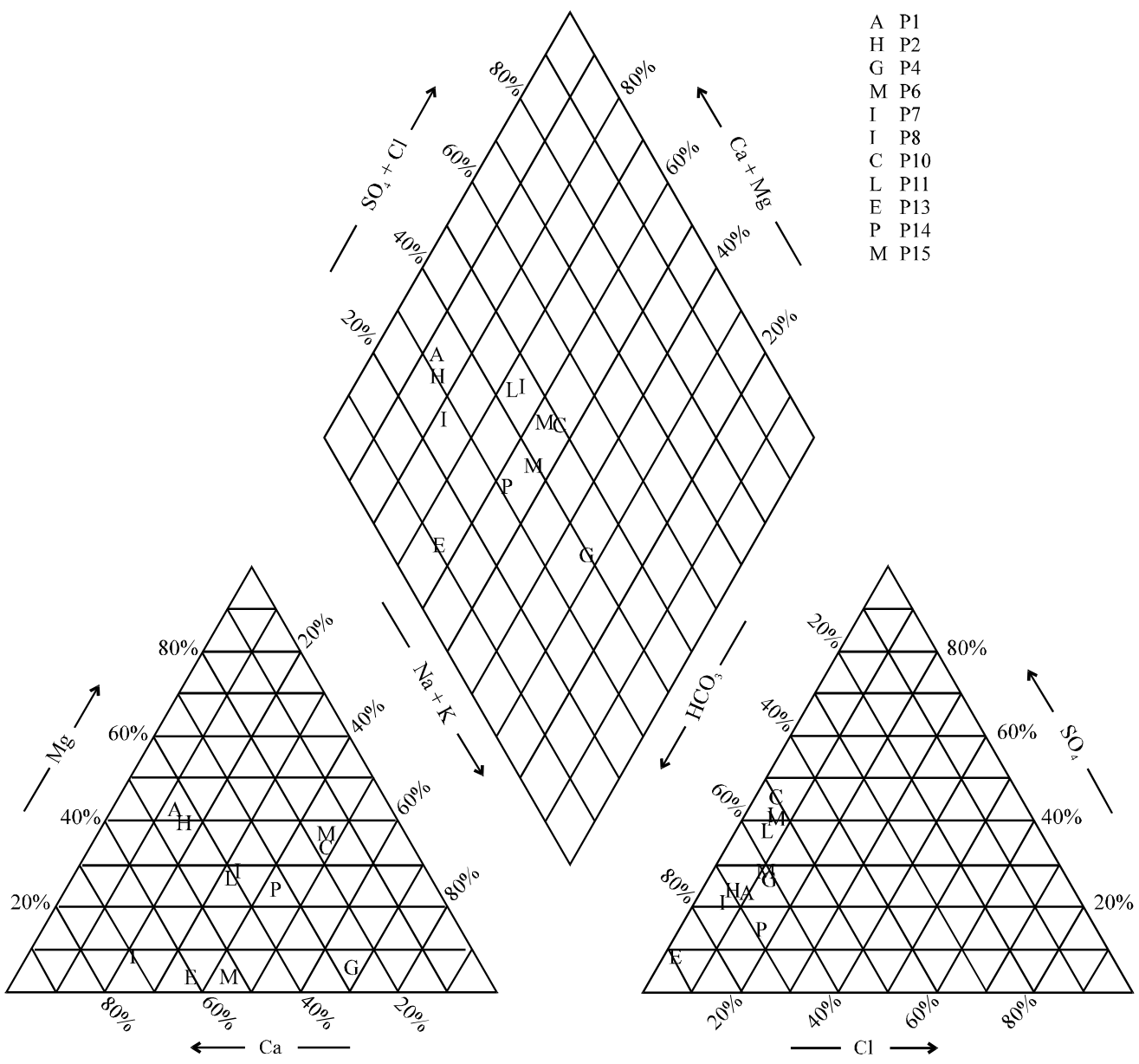

Fig. 6: Piper diagram of the water samples in zone study

the one hand and on the other hand between $\mathrm{Mg}^{2+}$ and $\mathrm{Na}^{+}$. These cation exchanges are supported by the presence of argillaceous minerals (Subba et al., 2006).
The major ions could come mainly from the water and carbonated minerals interaction and/or the water and silicated minerals interaction. The $\mathrm{Na} / \mathrm{Cl}$ ratio lies between 
Res. J. Applied Sci., 5 (5): 361-369, 2010

Table 3: Ionic ratios and chemical facies of the water samples

\begin{tabular}{|c|c|c|c|c|c|c|c|}
\hline Code & Locate & $\mathrm{Ca} / \mathrm{Mg}$ & $\mathrm{Na} / \mathrm{Ca}$ & $\mathrm{Na} / \mathrm{K}$ & $\mathrm{Na} / \mathrm{Na}+\mathrm{Cl}$ & $\mathrm{Na} / \mathrm{Cl}$ & Chemical facies \\
\hline P1 & TCHIALI & 1.00 & 0.14 & 0.72 & 1.07 & 0.58 & $\mathrm{Ca}-\mathrm{Mg}-\mathrm{HCO}_{3}$ \\
\hline $\mathrm{P} 2$ & CORAF & 1.07 & 0.20 & 1.02 & 1.05 & 1.18 & $\mathrm{Ca}-\mathrm{Mg}-\mathrm{HCO}_{3}$ \\
\hline P4 & LOANDJIII & 4.00 & 2.28 & 7.17 & 1.11 & 4.86 & $\mathrm{Na}-\mathrm{HCO}_{3}$ \\
\hline P6 & NKOUIKOU & 12.13 & 0.72 & 5.45 & 1.03 & 20.66 & $\mathrm{Ca}-\mathrm{HCO}_{3}$ \\
\hline $\mathrm{P} 7$ & ORSTOM & 1.31 & 0.93 & 21.43 & 1.11 & 15.10 & $\mathrm{Ca}-\mathrm{Na}-\mathrm{HCO}_{3}$ \\
\hline P8 & MATENDE & 7.44 & 0.20 & 1.26 & 1.05 & 2.42 & $\mathrm{Ca}-\mathrm{HCO}_{3}$ \\
\hline P10 & VOUNGOU & 0.49 & 2.82 & 37.98 & 1.04 & 175.33 & $\mathrm{Na}-\mathrm{Mg}-\mathrm{HCO}_{3}-\mathrm{SO}_{4}$ \\
\hline P11 & CERCLE & 1.34 & 0.81 & 16.28 & 1.14 & 11.19 & $\mathrm{Ca}-\mathrm{Na}-\mathrm{HCO}_{3}$ \\
\hline P13 & MBOUKOU & 13.54 & 0.55 & 7.99 & 1.02 & 24.56 & $\mathrm{Ca}-\mathrm{HCO}_{3}$ \\
\hline P14 & BRASCO & 1.29 & 1.32 & 18.16 & 1.21 & 13.82 & $\mathrm{Na}-\mathrm{Ca}-\mathrm{HCO}_{3}$ \\
\hline $\mathrm{P} 15$ & MPAKA & 0.42 & 2.81 & 41.14 & 1.16 & 36.79 & $\mathrm{Na}-\mathrm{Mg}-\mathrm{HCO}_{3}$ \\
\hline
\end{tabular}
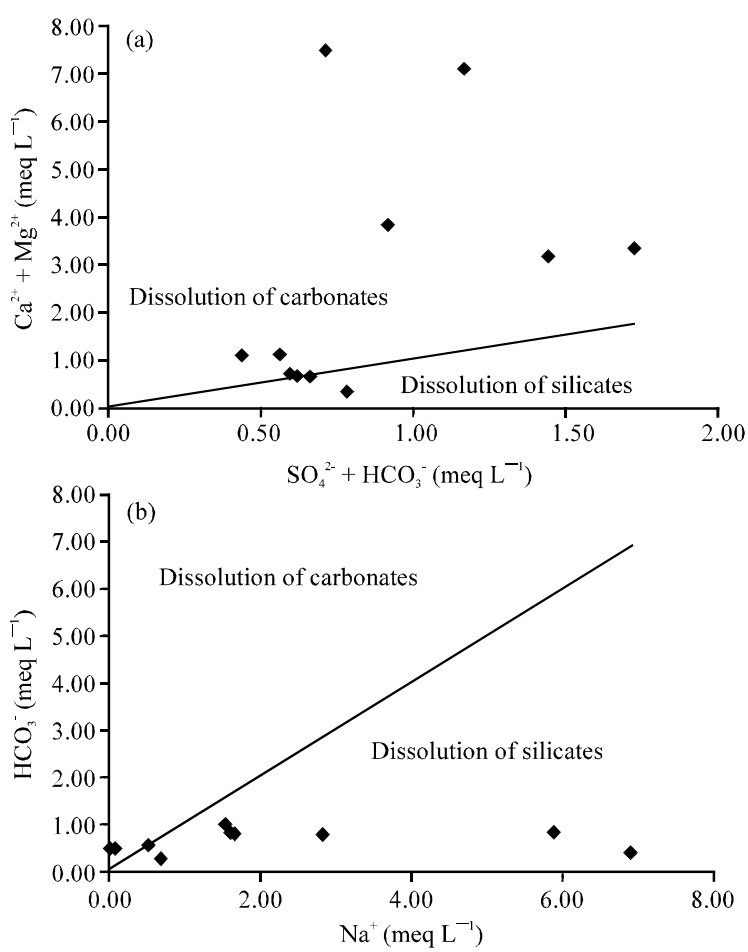

Fig. 7 a, b: Relation between $\mathrm{Ca}^{2+}+\mathrm{Mg}^{2+}$ and $\mathrm{SO}_{4}{ }^{2-}+$ $\mathrm{HCO}_{3}^{-} ; \mathrm{HCO}_{3^{-}}$and $\mathrm{Na}^{+}$

0.58 and 175.33. If sodium would come from the dissolution of halite, this ratio should be Equal to 1 . However, it is $>1$ in $90.90 \%$ of the water samples which indicates that the principal source of sodium is the dissolution of the silicates (Meyback, 1987).

Bicarbonate ion $\mathrm{HCO}_{3}^{-}$is the major anion which prevails in this water. The presence of carbonated minerals in the zone of recharge and the chemical dissolution of silicates are the principal factors which support the increase in the concentration in bicarbonated ion in groundwaters (Elango et al., 2003). Hydrochemical processes which control the chemical composition of the tablecloth namely dissolution of carbonates and silicates, ionic exchanges processes between cations were evaluated starting from the relations between major cations and anions (Datta and Tyagi, 1996; Giridharan et al., 2008; Jalali, 2007). These relations are illustrated on graphs whose straight line 1:1 makes it possible to delimit the dissolution field of carbonates from that silicates (Fig. $7 \mathrm{a}, \mathrm{b}$ ).

The Fig. 7a shows that the majority of the water samples is above the straght line $1: 1$, this indicates that the dissolution of carbonates is the dominating process which provides the ions calcium and magnesium in the tablecloth. In addition to the dissolution of carbonates, the dissolution of silicates represented by the chemical Eq. 1 also contributes to increase the concentration in $\mathrm{Ca}^{2+}$ and $\mathrm{Mg}^{2+}$ :

$$
\begin{aligned}
& \left(\mathrm{Na}^{+}, \mathrm{Mg}^{2+}, \mathrm{Ca}^{2+}, \mathrm{K}^{+}\right) \text {silicates }+\mathrm{H}_{2} \mathrm{O} \Rightarrow \\
& \mathrm{H}_{4} \mathrm{SiO}_{4}+\mathrm{HCO}_{3}-+\mathrm{Na}^{+}+\mathrm{Mg}^{2+}+\mathrm{Ca}^{2+}+\mathrm{K}^{+} \text {+ clays }
\end{aligned}
$$

The Fig. $7 \mathrm{~b}$ shows that the dissolution of silicates is the process which controls the chemical composition of the tablecloth compared to sodium. The relation between $\left(\mathrm{Na}^{+}+\mathrm{K}^{+}\right)$and $\left(\mathrm{Cl}^{-}+\mathrm{SO}_{4}{ }^{2-}\right)$ (Fig. 8a) shows that $\mathrm{Na}^{+}$and $\mathrm{K}^{+}$ present in the tablecloth neither come from salts such as the halite or sulphate of sodium, nor from potassium chloride or sulphate of potassium. This is also confirmed by the Fig. $8 \mathrm{~b}$ which shows the regrouping of the piezometers.

The presence of carbonates, sandstones, dolomites, marls announced in the lithography-stratigraphy of Pointe-Noire (Fig. 2) suggests that the dissolution of these minerals contributes to a significant degree to the increase of the concentration in ions $\mathrm{Ca}^{2+}, \mathrm{Mg}^{2+}$ and $\mathrm{Na}^{+}$.

The statistical data processing by ascending hierarchical clustering also made it possible to gather the piezometers in three classes. These classes are not other than the three regroupings obtained starting from the ionic ratio $\mathrm{Na} / \mathrm{K}$ in the water samples (Fig. 9). 

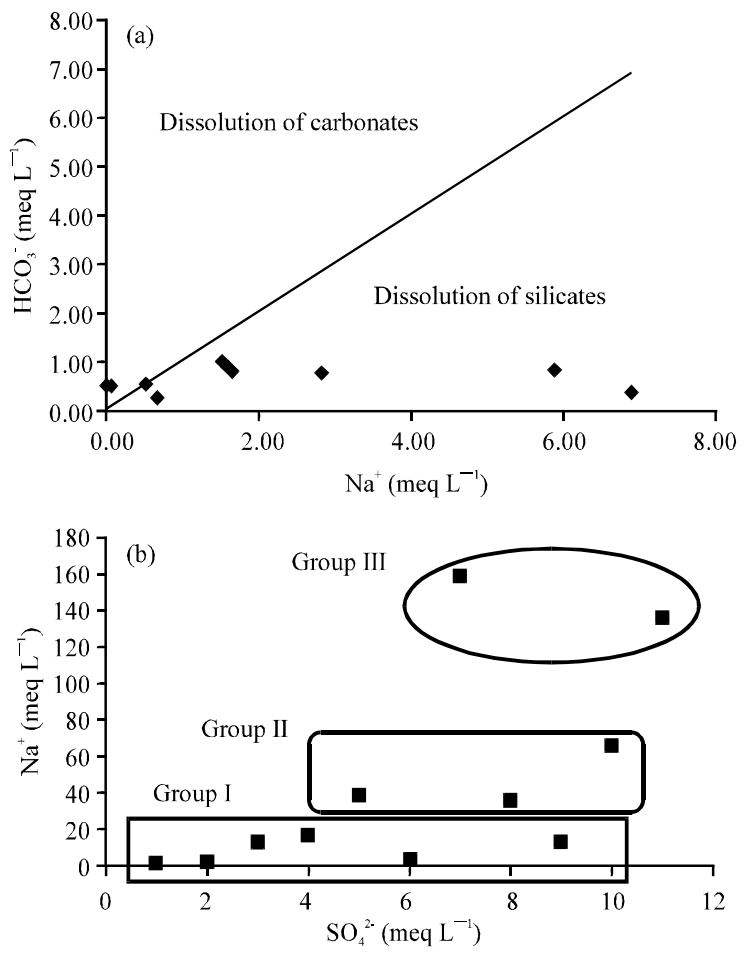

Fig. 8a, b: Relation between $\mathrm{Na}^{+}+\mathrm{K}^{+}$and $\mathrm{Cl}^{-}+\mathrm{SO}_{4}{ }^{2-}$; Relation between $\mathrm{Na}^{+}$and $\mathrm{SO}_{4}{ }^{2-}$

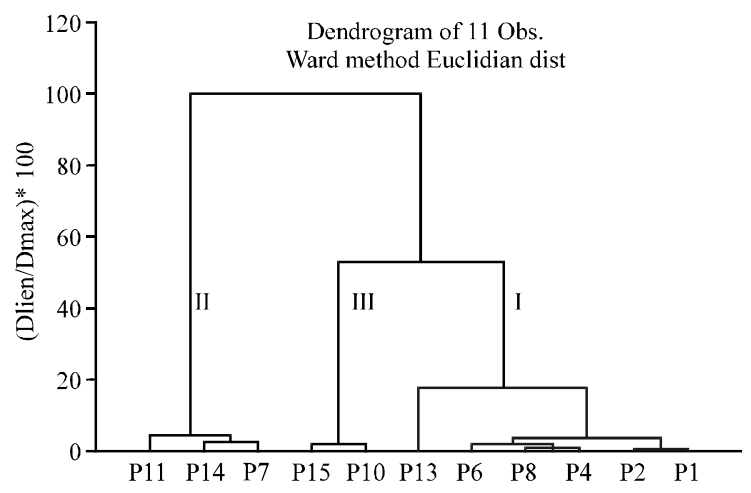

Fig. 9: Dendrogram of piezometers in study zone

\section{CONCLUSION}

The hydrochemical study of the aquifer AQ-2 whose aquifer is used by the national company of water distribution at Pointe-Noire in the south of Congo showed that the major cations and anions, the $\mathrm{pH}$, electric conductivity, the total dissolved solids, total alkalinity and the total hardness which characterize the chemical composition of the tablecloth are within the limits allowed for the drinking water according to standards $\mathrm{WHO}$. The hydrochemistry of the tablecloth in this aquifer varies in relation to the various interactions water-rock. Do the hydrochemical characteristics of aquifer show a prevalence of the cations $\left(\mathrm{Ca}^{2+}+\mathrm{Mg}^{2+}\right)$ on $\left(\mathrm{Na}^{+}+\mathrm{K}^{+}\right)$, of the ions bicarbonates $\mathrm{HCO}_{3}$ on the ions sulphates $\mathrm{SO}_{4}{ }^{2-}$ and chlorides $\mathrm{Cl}^{-}$. The ions bicarbonates come mainly from the dissolution of carbonated and silicated minerals.

While being based on the major components water of the tablecloth being studied corresponds to the chemical facies mixes cations $-\mathrm{HCO}_{3}$ and $\mathrm{Ca}-\mathrm{HCO}_{3}$ which account for $64 \%$ of the piezometers. The values of electric conductivity are relatively high in the south-west of zone study which lets suppose a probable influence of sea water on the chemical composition of water in this part of study zone.

The ratio $\mathrm{Na}^{+} / \mathrm{K}^{+}$allows a regrouping of the piezometers sampled in three groups which are confirmed by a statistical analysis of ascending hierarchical classification.

\section{REFERENCES}

APHA/AWWA, 1995. Standards Methods for Water and Wastewater Examinations. 21 Edn., American Public Health Association/American Water Works Association, Washington, DC USA.

Aris, A.Z., M.H. Abdullah, A. Ahmed and K.K. Woong, 2007. Controlling factors of groundwater hydrochemistry in a small island's aquifer. Int. J. Environ. Sci. Tech., 4: 441-450.

Datta, P.S. and S.K. Tyagi, 1996. Major ion chemistry of groundwater in Delhi area: Chemical weathering processes and groundwater flow regimes. J. Geol. Soc. India, 47: 179-188.

Elango, L., R. Kannan and M.S. Kumar, 2003. Major ion chemistry and identification of hydrochemical processes of groundwater in a part of Kancheepuran District, Tamil Nadu, India. J. Environ. Geosci., 10: 157-166.

Giridharan, L., T. Venugopal and M. Jayaprakash, 2008. Evaluation of the seasonal variation on the geochemical parameters and quality assessment of the groundwater in the proximity of River Cooum, Chennai, India. Environ. Monitor. Assess., 143: 161-178.

Jalali, M., 2007. Hydrochemical identification of groundwater resources and their changes under the impacts of human activity in the Chah basin in Western Iran. Environ. Monitor. Assess., 130: $347-364$. 
Meyback, M., 1987. Global chemical weathering of surficial rocks estimated From river dissolved loads. Am. J. Sci., 287: 401-428.

Ravindra, K. and V.K. Gark, 2007. Hydro-chemical survey of groundwater of Hisar City and assessment of defluoridation methods used in India. Environ. Monitor. Assess., 132: 33-43.
Subba, R.N., D.J. Devadas and K.V. Srinivasa, 2006. Interpretation of groundwater quality using principal component analysis from Anantapur district, Andhra Pradesh, India. Environ. Geosci., 13: 239-259.

WHO, 2004. Guidelines for Drinking Water Quality, Health Criteria and Other Supporting Information. 2nd Edn., Vol. 2, World Health Organization, Geneva, pp: 231-233. 